\title{
Dousa's Medieval Tournaments: Chivalry Enters the Age of Humanism?
}

\author{
Coen Maas
}

Ever since the emergence of medievalism in the early modern period, the tournament - rife as it is with chivalric associations - has been a dominant feature of the Middle Ages in the historical imagination. In modern times, famous tournament episodes, such as the one in Sir Walter Scott's Ivanhoe, may well have been an important factor that led to this result. ${ }^{1}$ Obviously, the key role of the tournament as a typical scene in medieval romance and its strong connections with the concept of courtly love made a major contribution to the fame of the tournament as well. ${ }^{2}$ Given the well-known disinclination of humanist scholars towards various facets of medieval culture and especially medieval literature, it might be expected that they would express an aversion to tournaments. From this point of view, it is perhaps not surprising that (mock) tournaments feature prominently in early modern parodies of chivalry, such as Pietro Aretino's Orlandino or Miguel de Cervantes' Don Quixote. At the same time, it must be acknowledged that the organization of tournaments continued well into the early modern period. Jacob Burckhardt described humanist attitudes towards these events as dismissive:

Da half es nichts, daß schon Petrarca sich mit dem lebhaftesten Abscheu über das Turnier als über einen gefährlichen Unsinn ausgelassen hatte; er bekehrte die Leute nicht mit seinem pathetischen Ausruf: 'man liest nirgends daß Scipio oder Cäsar turniert hätten!' Die Sache wurde gerade in

1 On the role of Scott in the formation of modern ideas about the Middle Ages, see, for instance, Chandler A., "Sir Walter Scott and the Medieval Revival", Nineteenth-Century Fiction 19, 4 (1965) 315-332; more recently, Alexander M., Medievalism: The Middle Ages in Modern England (New Haven - London: 2007), especially 24-64; Lynch A., "Nostalgia and Critique: Walter Scott's 'Secret Power", Postmedieval: A Journal of Medieval Cultural Studies 2, 2 (2011) 201-215.

2 See Blunk C.R., La vois des hiraus: The Poetics of the Tournament in Late Medieval Chronicle and Romance, $\mathrm{PhD}$ dissertation (University of Wisconsin-Madison: 2008); Bruckner M.T., "The Shape of Romance in Medieval France", in Krueger R.L. (ed.), The Cambridge Companion to Medieval Romance (Cambridge: 2000) 13-28, especially 19.

(C) COEN MAAS, 2019 | DOI:10.1163/9789004378216_013

This is an open access chapter distributed under the terms of the prevailing CC-BY-NC-ND License 
Florenz förmlich populär; der Bürger fing an, sein Turnier - ohne Zweifel in einer weniger gefährlichen Form - als eine Art von regelrechtem Vergnügen zu betrachten, und Franco Sacchetti hat uns das unendlich komische Bild eines solchen Sonntagsturnierers aufbehalten. Derselbe reitet hinaus nach Peretola, wo man um ein Billiges turnieren konnte, auf einen gemietheten Färbergaul, welchem dann durch Bösewichter eine Distel unter den Schwanz gebunden wird; das Thier nimmt den Reißaus und jagt mit dem behelmten Ritter in die Stadt zurück. Der unvermeidliche Schluß der Geschichte ist die Gardinenpredigt der über solche halsbrechende Streiche empörten Gattinn [sic].

It was in vain that from the time of Petrarch onwards the tournament was denounced as a dangerous folly. No one was converted by the pathetic appeal of the poet: 'In what book do we read that Scipio and Caesar were skilled at jousting?' The practice became more and more popular in Florence. Every honest citizen came to consider his tournament - now, no doubt, less dangerous than formerly - as a fashionable sport. Franco Sacchetti has left us a ludicrous picture of one of these holiday cavaliers a notary seventy years old. He rides out on horseback to Peretola, where the tournament was cheap, on a jade hired from a dyer. A thistle is stuck by some wag under the tail of the steed, which takes fright, runs away, and carries the helmeted rider, bruised and shaken, into the city. The inevitable conclusion of the story is a severe curtain-lecture from the wife, who is more than a little enraged at these neck-breaking follies of her husband. ${ }^{3}$

Janus Dousa the Elder (1545-1604), one of the foremost Neo-Latin poets in the Low Countries, also paid ample attention to tournament scenes when construing an appropriate medieval past for his country in his poetic work of history, the Annales rerum a priscis Hollandiae comitibus gestarum, published by Aelbrecht Hendrickszoon in 1599. The inclusion of these serious and extensive episodes is fascinating both in view of the sometimes satirical stance of humanist scholars towards the tournament, and in comparison with the historical tradition in Holland, in which tournaments occupy a fairly marginal

3 Burckhardt J.C., Die Cultur der Renaissance in Italien. Ein Versuch (Basel: 1860) 362-363; trans. S.G.C. Middlemore as The Civilisation of the Period of the Renaissance in Italy (Cambridge: 2014) vol. II, 118-119 (slightly adapted). The quote is from Petrarch, Epistulae seniles XI, 13: 'Nunquam sic lusisse Scipio legitur, nunquam Cesar'; when mentioning Sacchetti, Burckhardt refers to Novella LXIV. 
position. Why did Dousa decide to reserve so much space for these episodes? That is the question I would like to address in this article. In doing so, I will discuss Dousa's descriptions of three specific tournaments ${ }^{4}$ and demonstrate that in the Annales, various aspects of the tournament phenomenon were incorporated into Dousa's intricate literary programme and made to serve the political rhetoric of the work, demonstrating how the meaning attributed to tournaments in Dousa's medieval source texts was transformed to fit the early modern context.

In order to discern how Dousa integrated the medieval tournament into the structure of the Annales and to appreciate the transformation of its meaning and function in this process, attention should be paid to some literary and political background. Most importantly, it should be acknowledged that even though Holland was in some respects a peripheral region during the Middle Ages, this did not mean that the knightly tournament culture that flourished in many parts of Europe was absent there. Antheun Janse has shown that noblemen from Holland had participated in tournaments at least since the thirteenth century, and that the first tournaments organized in Holland took place no later than in the fourteenth century. These tournaments allowed participants to train their military skills, to display their martial prowess - especially to a viewership of noble ladies - and to distinguish themselves as members of the nobility. Tournaments organized by princes, often as part of court festivals, also served to consolidate the political and military support for their authority. From the fifteenth century onwards, the knightly character of the nobility in Holland seems to have been in decline, and Janse did not find evidence of tournaments held there during this period. ${ }^{5}$

In the historiographical tradition in Holland, tournaments play a subordinate role. The most important exception is the tournament held in Corbie

4 A fourth one, held in Trier in 1019, can be found in Dousa Janus, Annales rerum a priscis Hollandiae comitibus per CCCXLVI annos gestarum continuata serie memoriam complectentes (The Hague, Aelbrecht Hendrickszoon: 1599) 89. This short episode will not be taken into account here, as this part of the Annales was written by Dousa's son, so its contribution to the literary programme and political rhetoric of the work as a whole is more difficult to assess.

5 Janse A., "Toernooicultuur en adelscultuur in middeleeuws Holland", Holland. Regionaalhistorisch tijdschrift 34, 3 (2002) 150-166. See also Janse A., Ridderschap in Holland. Portret van een adellijke elite in de late middeleeuwen (Hilversum: 2001) 333-344. 
in 1234. Count Floris IV of Holland participated in this tournament and was killed. In the late thirteenth-century vernacular verse chronicle by Melis Stoke, and also in many later medieval and early modern works of history, the event is turned into a romantic tale. The Countess of Clermont had fallen in love with Floris and persuaded her husband to organize a tournament so that she would be able to admire him. Soon enough, she proved unable to hide her infatuation from her jealous husband. A violent combat between Floris, the husband, and their respective followers ensued, resulting in the death of both men. The Countess subsequently contracted the disease known as amor hereos (lovesickness) and died soon after. ${ }^{6}$ It has been remarked that the representation of this story is highly reminiscent of a medieval romance. ${ }^{7}$ This is not entirely surprising in view of the fact that tournaments were a staple ingredient of Middle Dutch Arthurian romances from the thirteenth century, such as Ferguut, Die Riddere metter Mouwen, and Walewein, which evolved around the concept of courtly love. In such stories, the tournament is part - and often the climax - of a series of adventures that the knight has to endure on his quest for a lady's favour. ${ }^{8}$

The literary configuration of the tournament in the romances was also put to effective use by the Habsburg dynasty that ruled the County of Holland following the death of Mary of Burgundy in 1482. In his autobiographical writings, Maximilian I heavily relied on literary motifs from the Arthurian tradition. ${ }^{9}$ Both Weisskunig and Theuerdank include tournament scenes, and Freydal is

6 Stoke Melis, Rijmkroniek van Holland, ed. J.W.J. Burgers (Hilversum: 1999) 122-124. Another important medieval version can be found in De Beke Johannes, Chronographia, ed. H. Bruch, Rijks geschiedkundige publicatiën. Grote serie 143 (The Hague: 1973) 181-183. The early sixteenth-century Divisiekroniek still follows this tradition: Aurelius Cornelius, Die cronycke van Hollandt, Zeelandt ende Vrieslant (Leiden, Jan Severszoon: 1517) fols. $162 \mathrm{v}-163 \mathrm{r}$. For the treatment of the story by the early humanist historian Reynier Snoy, see Maas C., The Medievalism and Political Rhetoric in Humanist Historiography from the Low Countries (1515-16og), Proteus 7 (Turnhout: 2018) 135-136.

7 Bruch H., "Floris IV sneuvelt in een tournooi", Spiegel Historiael 19 (1984) 93-96. See also Janse, Ridderschap in Holland 338. It may be added that the notion of amor hereos is closely linked to the concept of courtly love: Boase R., The Origin and Meaning of Courtly Love: A Critical Study of European Scholarship (Manchester - Totowa: 1977) 132-133. It is also interesting to note that in Der minnen loep, a didactic poem on love by Dirc Potter (ca. 1411-1412), the episode is interpreted as exemplifying a tragic but proper form of love: Potter Dirc, Der minnen loep, ed. P. Leendertz (Leiden: 1845-1847) vol. I, 153-158.

8 See, for instance, Smith S., "Een martiale monnik. Over moniage, tenue en toernooi in Die Riddere metter Mouwen", Voortgang. Jaarboek voor de Neerlandistiek 23 (2005) 33-9o (especially 33 and the literature mentioned in footnote 2).

9 Williams G.S., "The Arthurian Model in Emperor Maximilian's Autobiographic Writings Weisskunig and Theuerdank", Sixteenth Century Journal 11, 4 (1980) 3-22. 
completely dedicated to tournaments. Theuerdank, Maximilian's partly fictional narrative poem about his journey to marry Mary of Burgundy, was probably the most influential of these writings, as it was the only one to appear in print, in a beautiful 1517 first edition with woodcuts designed by, amongst others, Leonhard Beck, Hans Burgkmair the Elder, and Hans Schäufelein [Fig. 11.1]. Chapters 101-107 of the poem describe a tournament in which the noble knight Theuerdank, Maximilian's alter ego, defeats six adversaries in various types of combat, after which he is crowned with a laurel wreath by Queen Ehrenreich, Mary of Burgundy's fictional counterpart in the poem. ${ }^{10}$ Similarly, when Maximilian's great-grandson, the future Philip II of Spain, visited the Netherlands in 1549, an important part of the famous festivities held in Binche (Hainaut) consisted of tournaments. The festivities were carefully scripted symbolic performances in which Philip would emerge as victor, divinely ordained deliverer, and epitome of chivalric virtue, freeing prisoners from a dark castle with the help of an enchanted sword drawn from a pillar. The symbolism of the festivities clearly drew on chivalric literature, Amadís de Gaula in particular. In a German publication commemorating the celebrations, woodcuts from Theuerdank were reused, creating a certain continuity in the visual language used to represent the chivalric virtues of the Habsburg rulers. ${ }^{11}$

\section{Dousa's Political and Literary Commitments}

Janus Dousa the Elder's Annales rerum a priscis Hollandiae comitibus gestarum, the work that will be discussed in this paper, appeared in a different literary and political context than the chivalric tournaments of the Habsburg court. Dousa [Fig. 11.2] was deeply involved in the political scene of the Republic of the Seven United Netherlands, which had successfully broken away from its Habsburg king, Philip II of Spain, in 1568. Six years later, Dousa was charged with the defence of the city of Leiden against the troops of the duke of Alba. When the siege was lifted, it was decided that a university should be founded in the city. As a reward for his efforts, Dousa became a member of the new

\footnotetext{
10 Die Geverlicheiten und eins Teils der Geschichten des loblichen streitbaren und hochberümbten Helds und Ritters Tewrdanncks (Augsburg, Hans Schönsperger: 1519) fols. KV r-MIII r.

11 Frieder B.K., Chivalry and the Perfect Prince: Tournaments, Art, and Armor at the Spanish Habsburg Court, Sixteenth Century Essays and Studies 81 (Kirksville, MO: 2008) 135-158. See also Strong R.C., Splendor at Court: Renaissance Spectacle and the Theater of Power (Boston: 1973) 107-109; Peters E., "1549 Knight's Game at Binche: Constructing Philip II's Ideal Identity in a Ritual of Honour", in Falkenburg R. (ed.), Hof-, staats - en stadsceremonies, Nederlands kunsthistorisch jaarboek 49 (Zwolle: 1998) 11-35.
} 


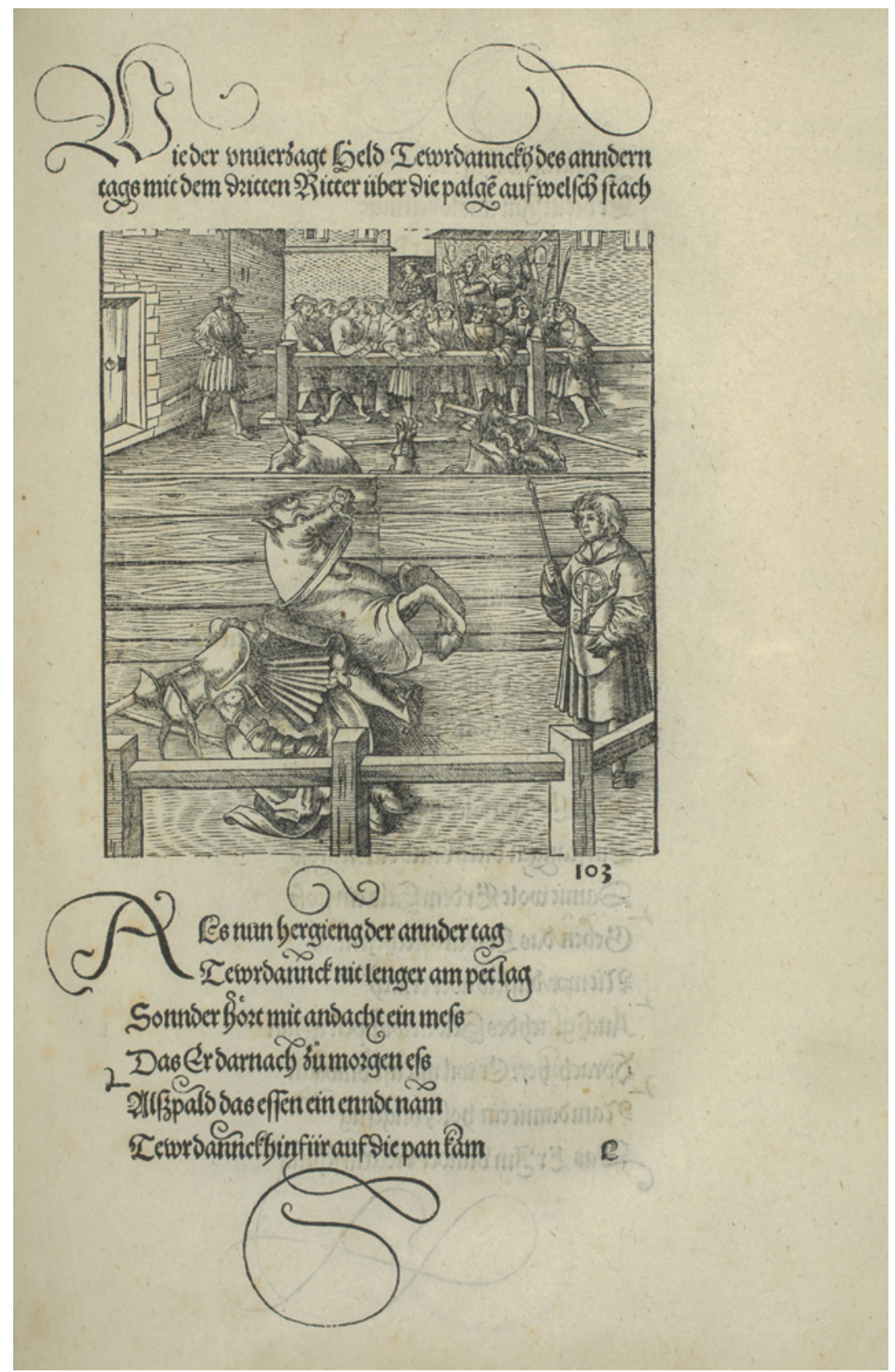

FIGURE 11.1 Leonhard Beck, woodcut depicting a jousting scene. From: Die Geverlicheiten und eins Teils der Geschichten des loblichen streitbaren und hochberümbten Helds und Ritters Tewrdanncks (Augsburg, Schönsperger: 1519). fol. L r (woodcut no. 103)

IMAGE (C) KONINKLIJKE BIBLIOTHEEK, THE HAGUE 


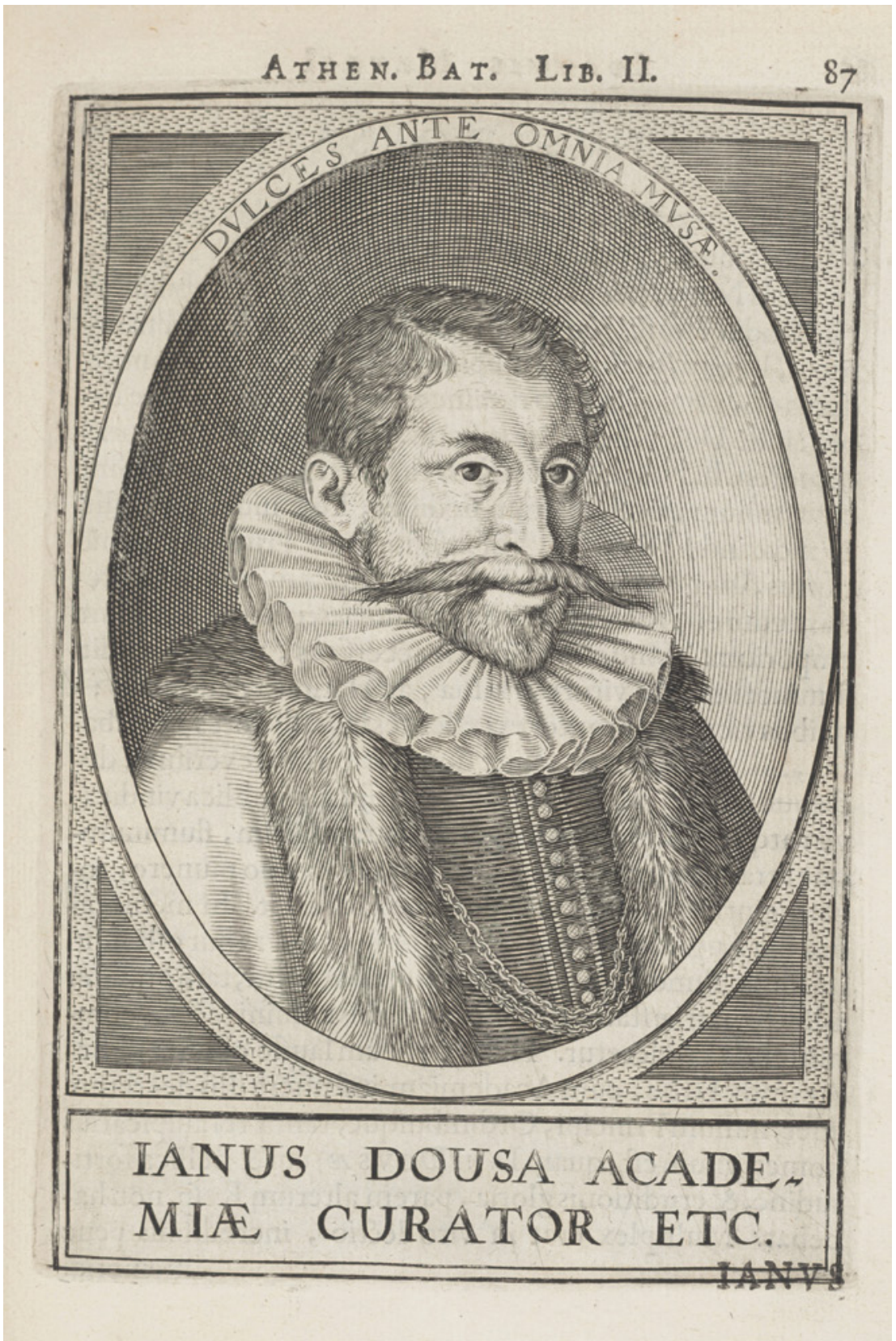

FIGURE 11.2 Willem van Swanenburgh, portrait of Janus Dousa the Elder. Engraving, taken from: Johannes Meursius, Athenae Batavae (Leiden, Andries Clouck - Officina Elzeviriana: 1625) 87 IMAGE (C) KONINKLIJKE BIBLIOTHEEK, THE HAGUE 
university's board. In the years 1584 and 1585 , he participated in embassies to Queen Elizabeth I of England. In 1591, he was appointed as a member of the Supreme Court of Holland, Zeeland, and West-Friesland. ${ }^{12}$

The genesis of the Annales rerum a priscis Hollandiae comitibus gestarum [Fig. 11.3] is also closely connected with the Dutch Revolt. In this work, Dousa describes the history of Holland from 841 until 1207. Until the publication of Dousa's works, knowledge about these centuries, when Holland was still a more or less independent county within the Frankish kings' sphere of influence, was only readily accessible in late medieval and early humanist works printed in the Low Countries under the Burgundian-Habsburgian regime; the newly founded Dutch Republic did not yet have a historiography of its own. ${ }^{13}$ Under these circumstances, the University of Leiden in 1585 commissioned Dousa to write a new prose history of Holland. This prose work was published in 1601; the metrical work of history, which will be examined in this article, was a product of the same historical inquiries and had been released two years before. ${ }^{14}$ After the publication of the prose history, Dousa was rewarded by the States of Holland with a golden chain and a medal worth six hundred pounds. In addition, he was granted an exemption from the obligation to appear in the Supreme Court. ${ }^{15}$

From a literary point of view, Dousa and his oeuvre are far removed from the conventions of the medieval romantic novel. Dousa was one of the foremost Neo-Latin poets and philologists of the late sixteenth century. He wrote various collections of Latin epigrams, odes, elegies, and satires after classical models; he compiled editions, commentaries, and collections of text-critical remarks for Sallust, Horace, Catullus, Tibullus, Petronius, and Sulpicia, and he contributed to the philological work of his sons on Plautus and Lucilius. Both

12 For the biographical facts, see Heesakkers C.L., Praecidanea Dousana. Materials for a Biography ofJanus Dousa Pater (1545-1604): His Youth (Amsterdam:1976); Heesakkers C.L.Reinders W.M.S., Genoeglijk bovenal zijn mij de Muzen. De Leidse Neolatijnse dichter Janus Dousa (1545-1604), Leidse opstellen 19 (Leiden: 1993); Vermaseren B.A., "De werkzaamheid van Janus Dousa $\mathrm{Sr}(\dagger 1604)$ als geschiedschrijver van Holland”, Bijdragen en mededelingen van het Historisch Genootschap 69 (1955) 49-107; Blok P.J. - Molhuysen P.C. (eds.), Nieuw Nederlandsch biografisch woordenboek (Leiden: 1911-1937) vol. vI, 425-429. Dousa himself describes the main outlines of his political career up to 1593 in Dousa Janus, Epistolae apologeticae duae (Leiden, Christophorus Raphelengius: 1593) 3-10.

13 For the development of historiography in Holland, see Kampinga H., De opvattingen over onze oudere Vaderlandsche Geschiedenis bij de Hollandsche historici der XVIe en XVIIe eeuw (The Hague: 1917).

14 For Dousa's commission to write a history of Holland, see Vermaseren, "De werkzaamheid" 58 .

15 Vermaseren, "De werkzaamheid" 65-66. 


\section{Quac sinc, in libri manginibis annotata suitr, upse Dorisa P. sevipsit. \\ IANI DOVSAE NORDOVICIS \\ ANNALES: \\ RER VM A PRISCIS}

HOLLANDIAE COMITIBVS PER CCC.

XLVI. Annos geftarum continuatâ feric memoriam complectentes.

NVNC PRIMITVS IN VNVM METRICE Historie Corpus redacit, atque $m$.X. Libros. tributi ac dispartiti.

\section{AD ILL VSTRES, NOBILES,} PRAPOTENTES, AC VERE MAGNIFICOS HOLLANDIE WESTFRISIAQV 2 ORDINES.

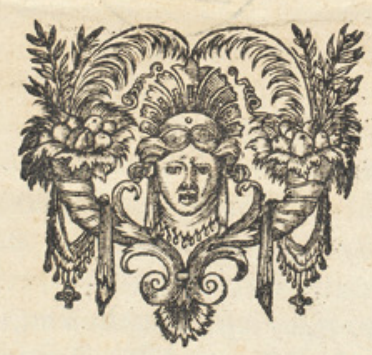

H A G 8 -COMITIS,

Ex officinâ Alberti Henrici. clo. Io: Ic.

C\&m Privilegio ad fexennium.

\section{Simm Abbes Cabbema. LINTENTO.}

FIGURE 11.3 Title page of Dousa's Annales (1599)

IMAGE (C) KONINKLIJKE BIBLIOTHEEK, THE HAGUE 
of Dousa's works of history are part of this classicist programme as well. The Annales rerum a priscis Hollandiae comitibus gestarum were written in Latin elegiac distichs and, as will be discussed in more detail below, follow the classical model of Ovid's Fasti rather than such examples as Stoke's verse chronicle or medieval epic poetry.

Since existing representations of tournaments in Holland were strongly connected with the literary genre of chivalric romance and the political propaganda of the Habsburg dynasty, Dousa's background as a humanist, as well as his active involvement in the war of independence against the Habsburg rulers of Holland, makes it very likely that the literary and political significance of medieval tournaments in the Annales rerum a priscis Hollandiae comitibus would be sharply different from that in the works of his medieval predecessors. The likelihood of discontinuity is increased even further when one takes into account the fact that Dousa was one of the few historians in the early modern Low Countries to refer to the Middle Ages as a chronological category by technical terms, such as media aetas and medium tempus, and employed this periodization to distinguish himself from previous historians. ${ }^{16}$ In the remainder of this article, it will be discussed how these discontinuities affected the representation of tournaments in the Annales.

The first tournament scene I would like to examine is the one set in Liège in the year 1048. The nucleus of the story about the tournament is as follows. Dirk IV, count of Holland, happened to be in Liège when a tournament was organized. Dirk participated in the tournament, but by accident he fatally wounded a nobleman who was a brother of both the archbishop of Cologne and the bishop of Liège. Although he was chased by a mob of angry knights, Dirk succeeded in leaving Liège and returning to Holland safely, but two of his own knights were killed. ${ }^{17}$

Dousa found this story in medieval chronicles from the fifteenth century, such as Johannes Gerbrandszoon a Leydis' Chronicon comitum Hollandie et episcoporum Ultraiectensium (the first version of which was written around

16 For an analysis of Dousa's concept of the Middle Ages, I refer the reader to Maas C., “'Covered in the Thickest Darkness of Forgetfulness': Humanist Commonplaces and the Defence of Medievalism in Janus Dousa's Metrical History (1599)", in Montoya A.C. Romburgh S. van - Anrooij W. van (eds.), Early Modern Medievalisms: The Interplay between Scholarly Reflection and Artistic Production, Intersections 15 (Leiden: 2010) 329-345. 
1468), the Florarium temporum (finished in 1472), and the Oude Goutsche chronycxken (first published in 1478). ${ }^{18}$ It is striking that Dousa was willing to use these sources here, since he usually rejected late medieval historiography as being unreliable. ${ }^{19}$ This critical attitude towards the tradition has in fact been praised as a vital catalyst for progress in Dutch historiography. Herman Kampinga, for instance, called Dousa a 'pathfinder in the field of scholarly historical investigation'. ${ }^{20}$ Although this reputation is generally by no means undeserved, the standards of reliability Dousa applied to the tournament in Liège are rather lax - a circumstance that may well suggest that the episode has special thematic significance for his work.

The chroniclers used by Dousa refer to the tournament as torneamentum, hastiludium, and tirocinium, but do not provide a detailed description of the event, nor do they give a clear interpretation. ${ }^{21}$ Dousa, on the other hand, manages to write two pages of verse in a rather detailed manner that he refers to in a marginal note as a Graphica Ludorum Equestrium [...] descriptio. ${ }^{22}$ This inflation of the historical sources was no doubt facilitated by the rhetorical techniques of exuberant text composition (copia) that played a key role in humanist education. Pupils were trained in expanding brief stories and arguments into full-fledged narratives and declamations. ${ }^{23}$ In De duplici copia verborum

18 Dousa, Annales 96, indicates that he used a manuscript of the Florarium temporum as well as some authors referred to as Annales nostrates.

19 For Dousa's critique of late medieval historiography in the verse Annales, see Maas, Medievalism and Political Rhetoric. 320-334.

$20 \quad$ Kampinga, De opvattingen 25-37. Cf. Waterbolk E.H., Twee eeuwen Friese geschiedschrijving. Opkomst, bloei en verval van de Friese historiografie in de zestiende en zeventiende eeuw (Groningen: 1952) 193-194, 201; Maas, Medievalism and Political Rhetoric 320-334, $348-353,383-385$. The quote is from Kampinga, De opvattingen 25 : 'padvinder voor de wetenschappelijke geschiedvorsching'.

21 For the version of the story in the Florarium temporum, see Bayerische Staatsbibliothek, MS. Clm 10436, fol. 176 r. For two examples of the late medieval chronicles Dousa might have used, see Leydis Johannes Gerbrandszoon, Chronicon Hollandiae comitum et episcoporum Ultrajectensium, ed. Franciscus Sweertius (Frankfurt, Daniel and David Aubry and Clemens Schleich: 1620) 124-125; Het oude Goutsche chronycxken van Hollandt, Zeelandt, Vrieslandt en Utrecht, ed. Petrus Scriverius (Amsterdam, Jan Hendrickszoon Boom, Joost Pluymer, and Casper Commelijn: 1663) 29.

22 Dousa, Annales 96.

23 See, for instance, Erasmus Desiderius, De ratione studii, ac legendi interpretandique authores libellus aureus (Strasbourg, Matthias Schürer: 1518) fols. VI v-VIII r. Erasmus briefly refers to the treatment of amplificatio in Quintilian, Institutio oratoria VIII, 4, 1-3. For the concepts of amplificatio and copia in the classical and humanist rhetorical tradition, see Bauer B., "Amplificatio", in Ueding G. (ed.), Historisches Wörterbuch der Rhetorik (Tübingen: 1992-2015) vol. I, 445-471, especially 449-452 (Middle Ages) and 452-457 (humanism); Cave T., The Cornucopian Text: Problems of Writing in the French Renaissance 
ac rerum, published in 1512 for St Paul's School in London, for instance, Erasmus had provided a comprehensive catalogue of strategies that could be used both to elaborate on the wording of any given discourse and to flesh out its subject matter. ${ }^{24}$ Hypotyposis (or descriptio, the term used in Dousa's marginal note) is one of the techniques in the second category: filling in concrete and vivid details about an event, the persons involved, their character and words, and the event's circumstances and consequences. Dousa thought that the uberior dicendi copia resulting from these was particularly fitting for poetic discourse, and indeed the descriptions of the tournaments in the verse Annales are much more extensive than their counterparts in his prose history. ${ }^{25}$

From an interpretive point of view, it is especially relevant to recognize what choices are made in expanding the source material. In this respect, it should be noted that in Dousa's description of the tournament in Liège, the chivalric aspects of the tournament are not very prominent. Although prowess and courage are, of course, present, other knightly virtues, such as piety, modesty, and loyalty, do not play a noticeable role in Dousa's account of this tournament, and the same is true of the concept of courtly love. The magical elements from the tradition of Arthurian romance are absent as well. Moreover, Dousa does not display a very keen interest in the precise execution of the tournament, although it seems that he is describing individual jousting rather than the traditional group fight known as mêlée. Rather, the more striking aspects of the passage are its visually suggestive character and the numerous references to epic subtexts. The following verses about the death of the nobleman and the reactions of the other participants provide a good example of these elements:

(Oxford: 1979) 3-34. For their role in humanist education, also see Mack P., "Humanism, Rhetoric, Education", in Hamilton D.B. (ed.), A Concise Companion to English Renaissance Literature (Malden, MA: 2006) 94-113, especially 103-104. Amplificatio was also a key ingredient of medieval poetics: Faral E., Les arts poétiques du XII ${ }^{e}$ et du XIII ${ }^{e}$ siècle. Recherches et documents sur la technique littéraire du moyen âge (Paris: 1924) 61-85.

24 Erasmus Desiderius, De duplici copia verborum ac rerum commentarii duo (Paris, Badius Ascensius: 1512).

25 For Dousa's comparison of poetic and historiographical discourse ("De poeticae artis cum historia Communione et Societatis"), see Annales fols. ${ }^{* *}$ IIII $\mathrm{r}-{ }^{* * * *}$ IIII v. The quote is from fol. *** III v. Cf. fol. *** $\mathrm{r}$ : 'vel rerum copia, vel sententiarum varietate abundantes'. On fol. *** IIII v Dousa lists a number of devices that can be used in poetry to prevent the reader from becoming tired or bored: figurarum varietas, temporum ac locorum descriptiones, similitudines, amplificationes, exempla, elogia, apostrophae, and orationes. For the descriptions of the tournaments in the prose history, see Dousa Sr. Janus - Dousa Jr. Janus, Bataviae Hollandiaeque annales (Leiden, Christophorus Raphelengius: 1601) 393-394, 394-395, 451, 457-458. On p. $45^{1}$ the reader is in fact referred to Annales $33^{-} 37$ for more detailed information about tournaments. 
Ille suo $<\mathrm{s}>$ flavos foedans in pulvere crines

Labitur, et pressam calcibus urget humum.

Intumuere Eburonum alae Germanaque signa:

Nil medium, caedem caede piare volunt.

'Devotum mactate caput'; vox omnibus una est.

Una nec unius iam petit hasta latus.

Tela volant, reboat Cataphractorum ictibus aether.

Me miserum, ludos hoc celebrare fuit?

Ille viam contra dextra laevaque timendus

Ferro aperit: Tungro sanguine terra rubet.

He falls, defiling his blond hair in the dust, and he burdens the soil pressed by his heels. The divisions from Liège and the German army rise: there is no middle course, they want to avenge slaughter with slaughter. 'Sacrifice that head vowed to God,' they all shout with one voice. More than one lance seeks the side of one man. Missiles fly and the air resounds with the blows delivered by the armoured knights. Poor me, was that a way to celebrate games? With his sword, the fierce count clears his way on the right and on the left: the soil turns red with the blood from Liège. ${ }^{26}$

The phrase foedans in pulvere crines in this passage is an allusion to the scene in the last book of the Aeneid where Turnus declares that he will fight Aeneas in single combat. ${ }^{27}$ This reference seems to add little more than generic epic flavour: it draws attention to bravery and physical prowess as key values in epic poetry.

The words vox omnibus una est, however, point towards a more specific epic background for Dousa's tournament scene. These words are borrowed from the fifth book of the Aeneid, in which the funeral games for Anchises are described. ${ }^{28}$ And it is not an isolated reference: Dousa uses at least three phrases from the fifth book of the Aeneid in his description of the tournament in Liège, ${ }^{29}$ which

26 Dousa, Annales 97.

27 Virgil, Aeneid XII, 97: 'semiviri Phrygis et foedare in pulvere crinis'. The phrase is also alluded to in Ilias Latina 323 ('Iliacoque tuos foedaret pulvere crines'), but I suppose the verse from the Aeneid - the more canonical work - would come to mind more readily for an early modern reader.

28 Virgil, Aeneid v, 616: 'et tantum superesse maris, vox omnibus una'.

29 Apart from the allusion mentioned above, the verse 'Nam vidisse parum est: belli simulacra ciere' (Dousa, Annales 96) refers to Aeneid v, 674 ('qua ludo indutus belli simulacra ciebat'), and the verse 'Mox tuba commissos solito canit ordine ludos' (Dousa, Annales 96) refers to Aeneid v, 113 ('et tuba commissos medio canit aggere ludos'). 
he also refers to as Ludicra Troiae, a term that is no doubt intended to conjure up the famous lusus Troiae that were introduced (or 'revived') by Julius Caesar in 46 or $45 \mathrm{BC}$ and for which Virgil provided the etiological underpinnings in the fifth book of the Aeneid. ${ }^{30}$ Thus, on the level of genre, the medieval tournament is turned into the equivalent of the games that had formed a standard ingredient of the classical epic genre since the description of the funeral games for Patroclus in the twenty-third book of Homer's Iliad. ${ }^{31}$ Dousa's tournament scenes contribute to the epic side of the Annales both as symbols of martial values and as counterparts to these epic games. The parallel between Dousa's Annales and Virgil's Aeneid also operates at the level of the events, however. At this level, a link is created between the glorious past of Holland and the illustrious history of the Roman Empire. This analogy seems particularly apt because Virgil's description of the funeral games for Anchises ends with the burning of several Trojan ships at Juno's instigation, while the next episode after the tournament in Liège is Dirk IV taking revenge by burning the merchant ships from Cologne and Liège in the port of Dordrecht.

The epic games from the Aeneid are not Dousa's only model at the event level, however. A second model should be mentioned here: Ovid's description of the battle of the Cremera, in which 306 members of the gens Fabia unsuccessfully fought against the Etruscans ( $477 \mathrm{BC}$ ). In the passage I just quoted, the relevance of this event is revealed by the words Tungro sanguine terra rubet, which are a variation on the words Tusco sanguine terra rubet from the second book of Ovid's Fasti. ${ }^{32}$ A second reference to Ovid's account of the battle of the Cremera is found a few pages later, when Dousa describes the battle at Dordrecht against an army raised by the archbishop of Cologne and the bishop of Liège, who were enraged at Dirk's burning of the ships. ${ }^{33}$ Again, the medieval tournament in Holland is presented as a re-enactment of ancient Roman history.

This presence of allusions to Ovid's Fasti is not entirely surprising. The Fasti served as the main mould for Dousa's work and provided the metre (elegiac

30 Virgil's description of the lusus Troiae can be found in Aeneid v, 545-602. See also Suetonius, Divus Iulius 39, and Cassius Dio XLIII, 23, 6, for Caesar's introduction of the game.

31 See, for instance, Lovatt H., Statius and Epic Games: Sport, Politics, and Poetics in the Thebaid (Cambridge: 2005), especially $\mathbf{1 - 2 2 .}$

32 Ovid, Fasti II, 212.

33 The verses are found in Dousa, Annales 99 ('Sic ventum in Batavos: quos postquam vincere aperte / Non datur, insidias gens Alemanna parat') and refer to Ovid, Fasti II, 213214 ('sic iterum, sic saepe cadunt; ubi vincere aperte / non datur, insidias armaque tecta parant'). 
distichs), the narrative patterns, and the main source of intertextual references. One might wonder, however, why Dousa decided to combine the models of the Fasti and the Aeneid, in the tournament scenes as much as in the rest of the Annales. The two models are easily reconciled, however, when one takes into account that for Dousa, Ovid's Fasti are a historical epic about the Roman people rather than a versified calendar. In his introduction, for instance, Dousa says that he opted for the gentler sound of the humble elegiac distich instead of the epic grandeur of the hexameter, 'after the example of Ovid, who was not working on a very dissimilar subject, when he wove most of the deeds of the people of Rome (Populi Romani Gesta) into the most exquisite scroll of his Fasti'. ${ }^{34}$ Both the Aeneid and the Fasti therefore seem to have played a role in the modelling of Dousa's Annales as a 'national' historical epic that glorifies the heroic past of his country and puts it on a par with the illustrious history of Rome. ${ }^{35}$

Of course, this laudatory perspective on the past, which is more or less inherent in the genre of (historical) epic, could be very convenient for people using it for contemporary reasons. Thus, Dousa chose to present the Annales as a kind of foundation myth for the newly founded Dutch Republic. In his introduction, he wrote:

Sed enim conclamatae paene Antiquitati ante omnia subveniendum, simul ad aborigines nostros, tanti Principatus conditores, oculatae mentis acies paulisper reflectenda, unde ad hoc pulcherrimum denique ac validissimum reipublicae corpus, quod hodie obtinemus, [...] perventum.

But yet above all, we should come to the assistance of antiquity, which has almost been bewailed [that is, it had been so grossly neglected that knowledge about it had nearly vanished], and at the same time we should for a while direct the keenness of our mental vision towards the original

34 Dousa, Annales fols. ** II v- ***II r: 'Ad Nasonis exemplum scilicet, qui non nimis absimili argumento plaeraque Populi Romani Gesta exquisitissimo Fastorum suorum Volumini intexuit'. For the idea that the Annales do not fit neatly within one literary genre, also see Heesakkers C.L., "Historia proxima poetis': la storia neolatina in versi di Janus Dousa sui conti di Olanda (1599)", in Nichilo M. de - Distaso G. - Iurilli A. (eds.), Confini dell'Umanesimo letterario. Studi in onore di Francesco Tateo (Rome: 2003) vol. II, 747-763, especially $760-761$.

35 This idea of a 'national epic' is reinforced by a third subtext, Ennius' Annales, which provided the title for Dousa's work and to which Dousa refers many times. For the role of Ennius in Dousa's verse history, see Maas, Medievalism and Political Rhetoric 312, 342; Heesakkers, "Historia proxima poetis" 761 . However, in the tournament scenes Dousa does not seem to make any specific references to Ennius. 
inhabitants of our country, the founders of such a great dominion, from which we have arrived at this exceptionally beautiful and strong body of the state that we have today. ${ }^{36}$

As I have argued before, one of the important objectives of the Annales in providing a glorious foundation myth for the Dutch Republic seems to be the creation of legitimacy for the Dutch Revolt against the Spanish authorities. ${ }^{37}$ Within that context, it may also be suggested that when Dousa describes in extenso the glorious feats of the counts of Holland during tournaments, he implicitly competes with the propaganda of the Habsburg court, which as has been described above - also relied on the tournament as a means to demonstrate its grandeur and legitimacy: the native leaders of Holland prove themselves to be virtuous champions of the people every bit as much as their foreign rivals.

Elegiac Love and Genre Experimentation: The Tournament in Magdeburg (937) [Fig. 11.4]

Dousa's interpretation of the Fasti as a historical epic does not mean that the genre play between epic and elegy that is so characteristic of the Fasti is absent from the Annales. On the contrary: the rivalry between both genres is carried on in the Annales, resulting in a degree of literary complexity that allows Dousa to incorporate different aspects of the tournament into his work. This can be seen especially well in the description of two other tournaments in the Annales, the ones set in Magdeburg in the year 937 and the one set in Rothenburg ob der Tauber in the year 942. The only information available to Dousa about these events was that Dirk II, count of Holland, participated in these tournaments - a fact that had been mentioned in Georg Rüxner's Turnierbuch (1530) and its Latin adaptation by Franciscus Modius, the Pandectae Triumphales (1586). In fact, it seems that both tournaments were completely made up by Rüxner, as there is no evidence for the existence of tournaments at all before

36 Dousa, Annales fol. ** v. Cf. 26 ('Hollandi conditor Imperii') and 68 ('tantae / Hollandam gentem condere molis erat', with an allusion to Virgil, Aeneid I, 33: 'tantae molis erat Romanam condere gentem'). Because of the patriotic tendencies in Dousa's poetic programme, Heesakkers calls the poem a 'national epic': for instance, Heesakkers, "Historia proxima poetis" $761-762$.

Maas, Medievalism and Political Rhetoric 307-308, 341-344. 


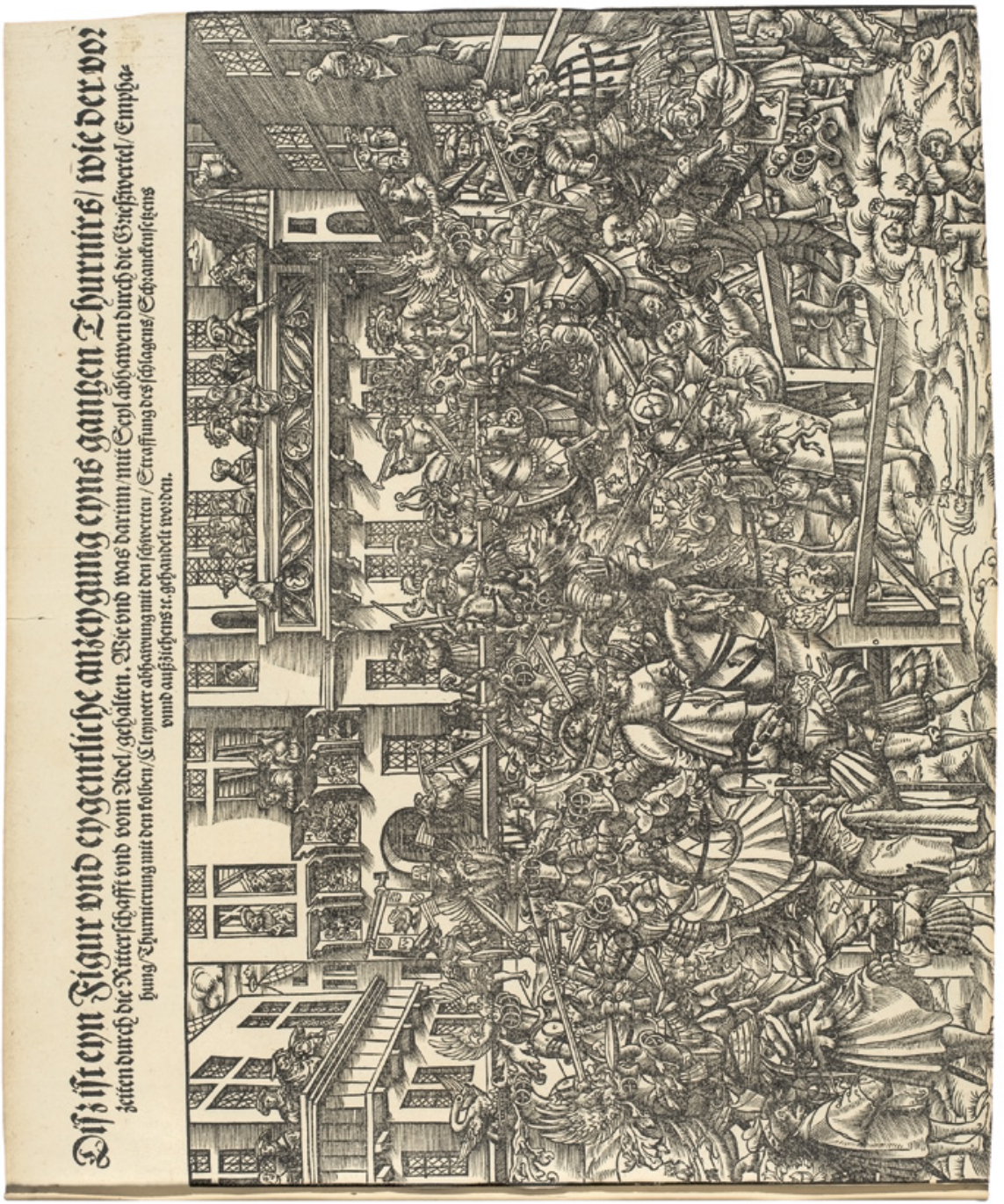

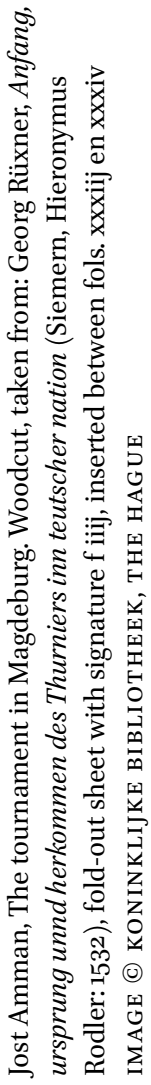

․․ 
the twelfth century. ${ }^{38}$ Again, Dousa here seems to assume a milder attitude towards his sources than he generally does, as he criticizes the chronological messiness of Rüxner's account without drawing the conclusion that Rüxner's account - which is not particularly rich in source references - is flawed on a more fundamental level. ${ }^{39}$

Despite his reputation for historical accuracy, Dousa succeeds in writing almost five pages of distichs about the event. In this passage, he situates the invention of the tournament in the time of Henry the Fowler, who was king of the Romans from 919 until 936. According to Dousa, the original aim of the tournament was to keep soldiers in shape in times of peace. Subsequently, the poet goes on to describe the three days' tournament in Magdeburg, allegedly held in the year 937. He refers to the preparations, the shining armour, the inspection of the helmets, the strict rules of the tournament, the punishments for non-compliance, the announcements by the herald, the sound of the trumpets, the participating noblemen who came from all over the Holy Roman Empire (with special attention given to the count of Holland, of course), the jousting with wooden lances (here Dousa probably means the Kolben, a kind of wooden club used in late medieval tournaments), and the crowds of female spectators. This description seems to be based almost entirely on information found in Rüxner's Turnierbuch. Especially for the origins of the tournament and its rules, it seems likely that Dousa consulted these sources, especially in view of the fact that the institution of the tournament by Henry the Fowler was an invention by Rüxner, who also projected the fifteenth-century rules of the game back onto this early period. ${ }^{40}$ This could also account for Dousa's anachronistic focus on the joust rather than the mêlée.

Dousa's verses about the interaction between men and women during the tournament are presented as part of a poetic digression from the martial subject matter of the work in general. Dousa asks Calliope, the muse of epic poetry, to follow him on the day before the lance fights begin, 'for Venus' day requires other games, other spectacles than these; she has given security to her

38 Jackson W.H., "The Tournament and Chivalry in German Tournament Books of the Sixteenth Century and in the Literary Works of Emperor Maximilian I", in Harper-Bill C. Harvey R.E. (eds.), The Ideals and Practice of Medieval Knighthood (Woodbridge: 1986) 49-73, especially 51. For the origins of the tournament, see also Keen M.H., Chivalry (New Haven: 1984) 83-84.

39 In fact, Dousa even vouches for Rüxner's truthfulness. See Dousa, Annales 37: 'Nam quod ad Hollandum Comitem, et Gotha pertinet arma, / Ruxnero certum est credere: vera refert'. Dousa limits his critique to Rüxner's chronology, which he refers to here as 'hallucinatio in temporum ratione perperam subducta'. This point is explained in more detail in Dousa Sr. - Dousa Jr., Bataviae Hollandiaeque annales 394-395. Jackson, "The Tournament and Chivalry" 51. 
husband Mars'41 At the end of the digression, Dousa explicitly indicates that he regards the excursus as elegiac:

But it will be time to cut short the games, after the pressed hair has borne the helmet long enough. There has been more than enough indulgence in arms and broken lances. Therefore, return to the Fasti now, Elegy; from this by-road we have to go back to the Fasti in orderly fashion, giving everyone the praise he deserves. ${ }^{42}$

In Dousa's description of the tournament in Magdeburg, the ample attention paid to the presence of women and the heavy emphasis placed on the romantic aspects of the tournament are striking, especially in contrast to the way he described the tournament in Liège, which was characterized by a focus on the martial aspects of the spectacle. ${ }^{43}$ I will quote a few verses from the former passage to illustrate my point. According to Dousa's marginal notes, the words between quotation marks (added here by myself) should be understood as being spoken by the young participants in the tournament.

Rarus honos, nympharum encomia posse mereri;

Rarior, a cara pignora ferre manu.

Nec mihi quis regum dona, aut praeconia iactet.

An tribui hac merces dignior ulla potest?

O decora, o nostrae merces male cognita pubi;

Illa quoque Hesperium trans mare digna peti.

'Solus honesta equiti scisti dare praemia, Caesar:

Haec mihi si dederis, iam cataphractus ero.

41 Dousa, Annales 35: 'Cras, (ut rumor ait,) puris certabitur hastis. / Spectatum, o, mecum (Calliopeia) veni. / Quippe alios ludos, alia his spectacula poscit / Lux Veneris; Marti sat dedit illa suo'. It is somewhat unclear to me to which days exactly Dousa is referring. The tournament was held on Tuesday, Wednesday, and Thursday, according to his account (see also Rüxner Georg, Anfang, ursprung unnd herkommen des Thurniers inn teutscher nation, Siemern, Hieronymus Rodler: 1532, fols. XXXII v-XXXIII v). The day before the lance fights cannot be Friday, then, as the phrase lux Veneris may suggest.

42 Dousa, Annales 37: 'Sed iam tempus erit ludos incidere, postquam / Sat galeam pressae sustinuere comae: Indultumque armis, et rupta hastilia abunde; / Proinde iterum ad Fastos nunc (Elegia) redi; / A diverticulo repetendos ordine Fastos: / Elogium tribuens unicuique suum'. Note that Dousa uses the term ludi again, which may be taken as another reference to the phenomenon of epic games (see, for instance, Virgil, Aeneid v, 113 and 605).

43 Perhaps the idea was suggested to Dousa by the name of city ('the city of virgins'), to which he refers by both its German name (Magdeburg) and its Greek version (Parthenope)? 
Formosae, o, tantum spes sit placuisse puellae.

Cedet Amiclaeo iam mihi Castor equo.

Nam mihi quo plausus, quo niceteria vulgi,

Eludit palmas si domina una meas?

Da veniam, Caesar: nec iam tua Munera tanti:

Et satis est, faveat si Pasicompsa mihi'.

It is a rare honour to be able to deserve the praise of the maidens; even rarer to take up the tokens from a precious hand; let no one take pride with me in royal proclamations and gifts. Or can any worthier reward be assigned than that one? Oh, the glory and rewards that are so badly known to our youth! They are also worthy of being pursued beyond the Western sea. 'Only you, Caesar, were able to give honourable rewards to the knight: if you give them to me, I will be your armoured knight. Oh, let there only be hope to have pleased the beautiful girl - even Castor will give way to me on his Laconian horse. For how can the applause and the prizes of the people be of any use to me, if my only mistress mocks my palms of victory? Forgive me, Caesar, your gifts are not worth that much: and it is enough if Pasicompsa is well disposed towards me. ${ }^{44}$

In this passage, Dousa leans heavily on classical love poetry, although subtle differences are noticeable. The words trans mare digna peti, for instance, are borrowed from the Heroides, specifically the letter from Leander to Hero. ${ }^{45}$ In this letter, Leander says that he would cross the sea for Hero's kisses; in Dousa's work, the speaker's attention has a more symbolic and sublimated focus: the tokens of favour (pignora) given by the noble ladies to the most successful knights, described by Rüxner as a wreath (Kränzlin, translated by Dousa as serta) with a piece of jewellery. ${ }^{46}$ In addition, Dousa quotes another verse from the Heroides, this time from Helen's letter to Paris. ${ }^{47}$ While Helen admits that Paris' gifts are not enough for her to stay with him, Dousa reverses the situation

44 Dousa, Annales 36 . The marginal notes read: 'Huc iuvenes aequum est contendere'. And: 'Ex quorum persona potius, quam ex mea, cum haec tum quae sequuntur dicta accepi velim; Ornatus tantum gratia a nobis intertexta hoc loco, more poetis non inconsueto'. Ovid, Heroides XVIII, 102: 'oscula, di magni, trans mare digna peti!.

46 Rüxner, Anfang, ursprung unnd herkommen fol. XviII r: 'welche Vier in solchem Thurnier vnd Ritterspil das best thetten, das die für die andern globt vnd gepreißt wurden, denen gaben Frawen vnd Junckfrawen den danck; das was eyn Kräntzlin bei weilen mit eynem angehenckten Cleynodt oder hefftlin'. Dousa, Annales 36: 'Serta, inserta suo quae bacca ornaverit auro, / Serta, favor dantis quae pretiosa facit'.

Ovid, Heroides XVII, 225: 'da veniam fassae! non sunt tua munera tanti'. 
and has the speaker reject the emperor's rewards in favour of the love of his elegiac mistress (domina), referring to her as Pasicompsa, which is the name of a character in Plautus' Mercator who is sought as a mistress by several other characters. And thirdly, together with a few other words, the phrase haec mihi si dederis refers to the description of the rape of the Sabine women in Ovid's Ars amatoria. ${ }^{48}$ While Ovid suggests that he would like to be one of the Romans involved in that story if could get the accompanying commoda, the speaker in Dousa's poem would like to become a knight if he could obtain the honesta praemia promised by the emperor.

In this way, Dousa enters into a competition with Ovid, and it seems that he tries to outdo Ovid by proposing the tournament as a more sublimated, elevated, and chaste type of love. ${ }^{49}$ It may well be that this representation of the tournament is ultimately inspired by chivalric descriptions of tournaments in medieval romances, although classical poetry always remains the main frame of reference for Dousa. ${ }^{50}$ At the level of genre, the passage shows that Dousa is not a typical epic poet. After the model provided by Ovid's Fasti, he blends elegiac elements into his heroic poetry, thus continuing Ovid's playful exploration of the border zone between epic and elegy in the Fasti. ${ }^{51}$

Loyalty and Respect: The Tournament in Rothenburg ob der Tauber (942)

After describing the role of the women during the tournament in Magdeburg, Dousa's poetic narrator interrupts his digression with Ovidian selfconsciousness, ${ }^{52}$ recapitulates his narrative about Dirk II, and mentions in

48 Ovid, Ars amatoria I, 131-132: 'Romule, militibus scisti dare commoda solus: / Haec mihi si dederis commoda, miles ero'.

49 Another sign of competition is that Ovid's simple foot soldier (miles) becomes a more respectable cavalryman (eques) in Dousa's verses.

5o For the reuse of medieval love poetry in humanist elegy, see also Pieper C.H., "Medievalisms in Latin Love Poetry of the Early Italian Quattrocento", in Montoya A.C. - Romburgh S. van - Anrooij W. van (eds.), Early Modern Medievalisms: The Interplay between Scholarly Reflection and Artistic Production, Intersections 15 (Leiden: 2010) 45-66.

51 The literature on the genre experiment carried out in the Fasti is quite voluminous; see Hinds S., "Arma in Ovid's Fasti. Part 1: Genre and Mannerism", Arethusa 25, 1 (1992) 81-112, and, more recently and extensively, Merli E., Arma canant alii. Materia epica e narrazione elegiaca nei Fasti di Ovidio, Studi e testi 16 (Florence: 2000).

$5^{2}$ In any case, the expression seems Ovidian, but one may even surmise Dousa is referring to Ovid, Tristia v, $7,55^{-5}$, specifically: 'ille ego Romanus vates (ignoscite, Musae!) / 
passing Dirk's participation in another tournament, the one allegedly held by Conrad the Red, duke of Lorraine, in Rothenburg ob der Tauber in the year 942:

Nec minus (o) vati, cives, ignoscite vestro,

Rumpere qui coepti propositi ausus opus.

Illustris fidei unde liquet documenta dedisse

Instructum Hollandis Didericum ordinibus.

Inter praecipuos tunc Caesaris auxiliares;

Praemiaque ad patrios Hunna tulisse Lares.

Didericum dico, comitum qui in classe secundus,

Tunc cui maturo robore flos aderat.

Quique Gothis prope tres annos exercitus armis,

Durarat primae tempore militiae.

Hunc etiam, spumantis equi dum assurgit in armos,

Munus honestantem, (dux Lotharene,) tuum:

Hastifragumque, Rotenburgicae sub moenibus urbis,

Victorem Tubarus vidit, et obstupuit.

Francica Thuringos qua cis patet area saltus.

Quintus ab Henrici munere is annus erat.

And, my fellow countrymen, forgive your poet just as much, who ventured to interrupt the work on the subject I had embarked on, which demonstrates that Dirk, placed among the ranks from Holland, proved his exceptional loyalty and that among Caesar's distinguished auxiliary troops, he brought Hunnic spoils back to his fatherland. I mean Dirk, who was the second Count, and who was then in the prime of his mature strength. In the period of his first military service, he spent almost three years fighting in Germany. When this man mounted the shoulders of his foaming horse - honouring your spectacle, Duke of Lorraine - the Tauber saw this lance-breaking victor under the walls of Rothenburg, where the Frankish land stretches on this side of the Thuringian forests, and it was stupefied. It was the fifth year after Henry's spectacle. ${ }^{53}$

In this passage, Dousa returns to the martial aspects of the tournament and presents them as a source of awe. In doing so, he refers to Propertius' rejection

Sarmatico cogor plurima more loqui'. For the Ovidian characteristics of the Annales in general, see Maas, Medievalism and Political Rhetoric 334-343. 
of military life, so characteristic of elegiac poetry. ${ }^{54}$ Again, some contrast imitation might be at work here, because unlike the spoils of war mentioned by Propertius, Dirk's praemia are no longer dira but merely 'Hunnic'; Dousa presents the war against the Magyars (Hunni) as a praiseworthy enterprise. In the rivalry between epic and elegy, Dousa thus seems to take the emancipation of elegiac poetry to a higher level, and self-consciously describes epic subject matter in elegiac distichs. The point is underscored by the epic language of the passage. ${ }^{55}$

What is more important for my argument, however, is that Dousa presents Dirk's willingness to follow the emperor to the German lands in the east for three full years, to fight in his battle against the Magyars at Merseburg, ${ }^{56}$ and to participate in the tournaments held during this period, as an exceptional display of loyalty (illustris fides) to the feudal system of which he was a part. The words munus honestare convey a similar sense of social obligation. This representation fits in well with the actual social functions of tournaments - one of which was to strengthen the political and military ties of the participating noblemen to the prince who organized the tournament - and it might contain a remnant of the chivalric ideal of loyalty. However, Dousa's focus on loyalty is also salient in view of the political discourse of the Dutch Revolt. At least until 1580, the propaganda of William of Orange heavily relied on the concept of fealty - the fidelity owed by a vassal to his feudal lord - and to justify his actions he consistently used the argument that his duty of loyalty to Philip II required that he defend the common weal. ${ }^{57}$

Similar arguments were made on behalf of the people as a whole. Some fine examples can be found in a speech by Philips of Marnix, Lord of SaintAldegonde [Fig. 11.5], held at the Diet of Worms in 1578. The speech has been characterized by Martin van Gelderen as 'yet another historical account which presented the Dutch as most faithful subjects. ${ }^{58}$ In this speech, Marnix referred to the 'States and their continuous and steadfast loyalty ( fides) and respect

54 Propertius, Elegiae II, 30, 22: 'et ferre ad patrios praemia dira Lares!'.

55 For the 'foaming horse', for instance, compare Virgil, Aeneid VI, 881 ('seu spumantis equi foderet calcaribus armos'); for fighting 'under the walls of the city', compare Virgil, Aeneid XII, 116 ('campum ad certamen magnae sub moenibus urbis').

56 The battle took place in the year 933, but Dousa seems to date the event to the year 935 .

57 Oudendijk J.K., "Den Coninck van Hispaengien heb ick altijt gheert", ed. W. Jappe Alberts, Dancwerc. Opstellen aangeboden aan Prof. Dr. D.Th. Enklaar ter gelegenheid van zijn vijfenzestigste verjaardag (Groningen: 1959) 264-278.

58 Gelderen M. van, The Political Thought of the Dutch Revolt, 1555-159o, Ideas in Context 23 (Cambridge: 1992) 139. Marnix' plea was directed towards the princes of the Holy Roman Empire, and he aimed to obtain their support for the cause of the Dutch Revolt. Although this may seem to constitute a parallel to Dirk II's service to the emperor, Dousa seemed 


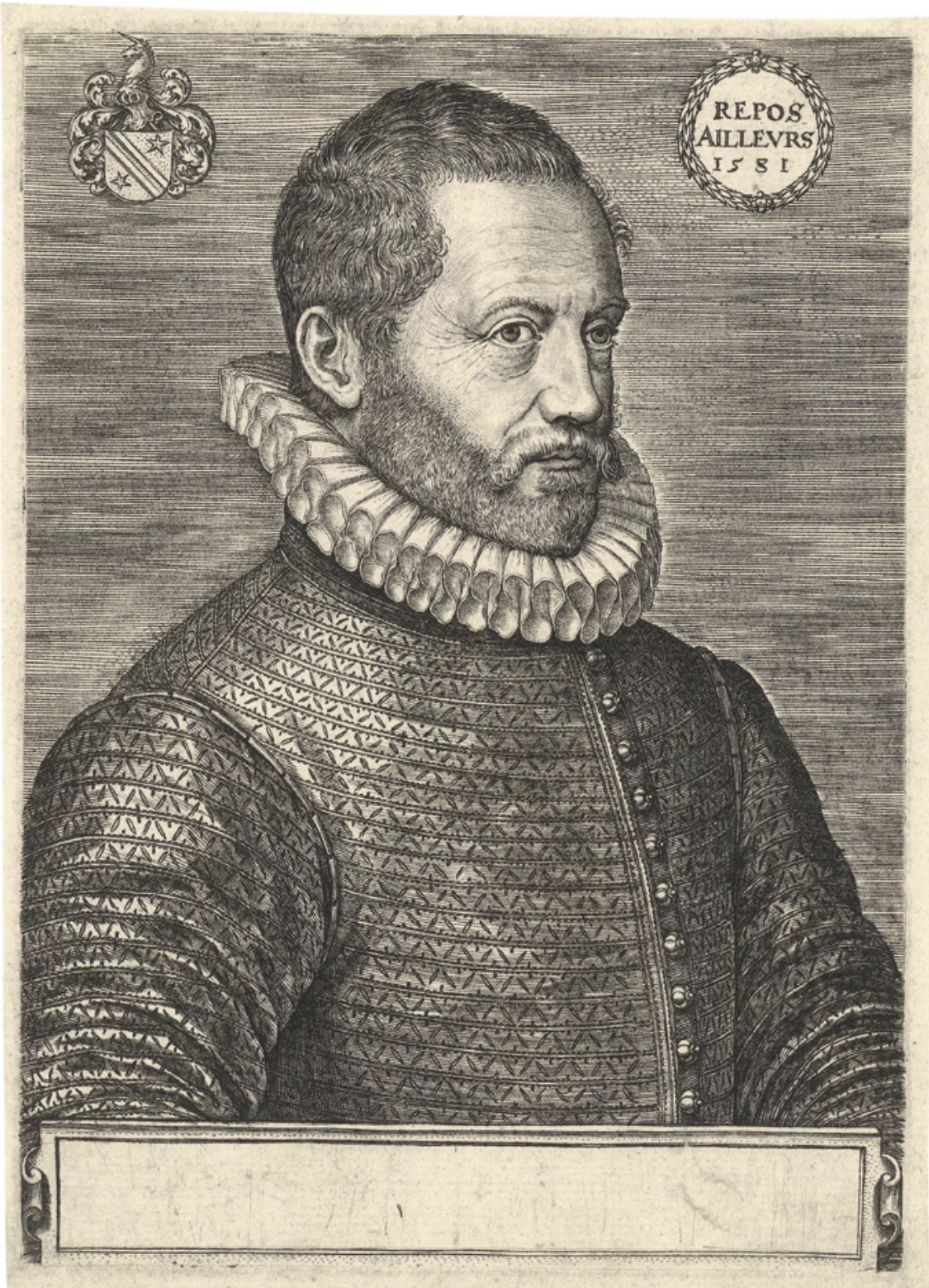

FIGURE 11.5 Johan Wierix, portrait of Philips of Marnix (1581). Engraving IMAGE (C) RIJKSMUSEUM, AMSTERDAM 
(observantia) towards the King of Spain, their legitimate lord and natural ruler'. In addition, he mentioned 'those ancient examples of the loyalty ( fides), affection (amor), and unbroken and unvanquished respect (observantia) of the Dutch towards their rulers and lords, a respect that has been perpetuated by our forefathers from the very beginning for all time.,59

That this idea had not lost its relevance at the time of the publication of Dousa's Annales can be observed in pamphlets like De iure belli Belgici, printed by Aelbrecht Hendrickszoon one year before he issued the Annales. The writer of this pamphlet claimed it was widely known

that the inhabitants of Holland and Zeeland have always supported and followed the King's reign with full sense of duty and obedience - as if it was some revelation of divine will - and that nothing, indeed, was ever lacking in the loyalty (fides) and obedience (obsequium) they owed to their rulers in accordance with the laws of nature. ${ }^{60}$

From this perspective, Dousa's representation of the loyal behaviour of Count Dirk II can be regarded as part of a broader narrative about the enduring faithfulness of Holland to its rulers. Dirk's tournament participation thus prefigures the strong sense of loyalty in which the early modern Hollanders and their

to have looked for support from France rather than from the Holy Roman Empire: Maas, Medievalism and Political Rhetoric 325-326.

59 Marnix Philips of, Oratio [...] pro serenissimo archiduce Austriae Matthia, et Ordinibus Belgicis, ad delegatos septemvirum, ceterorumque principum, et ordinum Sacri Imperii, Wormatiano conventu habita (unknown printer: 1578) 9: 'ordines et suam in regem Hispaniarum, legitimum suum dominum, ac principem naturalem, perpetuam et constantem fidem atque observantiam, et in gravissima, atque indigna liberis hominibus, perdiuturnaque Hispanorum oppressione patientiam, ac moderationem incredibilem, et denique ad constituendam pacem, avertendasque huius belli faces propensionem, ac studium flagrantissimum'. The second quotation is on p. 10: 'vetera illa Belgarum erga suos principes ac dominos fidei, amoris, et infractae invictaeque observantiae, iam inde usque a maioribus omni aevo perpetuatae exempla'. See also p. 13: 'admirabili eorum fide ac liberalitate' and p. 20: 'perpetuam suam et constantem erga regem fidem'.

6 De iure belli Belgici adversus Philippum regem Hispaniarum oratio (The Hague, Aelbrecht Hendrickszoon: 1598) 57: 'quandoquidem inter omnes, non Belgas modo, sed quoscunque exteros homines constat, qui tum ipsi rem omnem, uti gesta est viderunt, vel postea auditione acceperunt, Hollandos, Zelandosque omni officio et obsequio semper Regis imperia, tanquam oracula quaedam suscepisse et peregisse: Nunquam vero defuisse fidei suae atque obedientiae, quam naturae legibus debebant suis principibus'. See also p. 9, where reference is made to Governor Mary of Hungary's testimony to Philip II about the 'fidem ac virtutem Belgarum'. 
leaders took so much pride. ${ }^{61}$ In this way, Dousa incorporates yet another aspect of the chivalric code of honour that is at the core of many medieval tournament representations into the political message of his own tournament scenes - a political message that was itself deeply rooted in feudal concepts of fidelity.

In this article, I have discussed three tournament scenes from Janus Dousa's verse history of Holland, proposing a few possible explanations for the relatively large amount of attention he pays to these episodes. I pointed out that in the Annales Dousa follows the model of Ovid's Fasti and continuously balances between the classical literary genres of epic and elegy. The medieval phenomenon of the tournament fit this elaborate literary programme exceptionally well. On the one hand, Dousa paid considerable attention to the amorous side of the tournament. Love between knights and female spectators becomes part of a web of allusions to classical elegiac poetry, which Dousa seems to be emulating by presenting the interaction between knights and noble ladies at the tournament as a purer and more elevated kind of love, possibly evoking some chivalric overtones of courtly love here. On the other hand, the tournament is also - and more importantly - a symbol for the martial virtues of the counts of Holland. From this perspective, the tournament scenes - sometimes even represented as epic games, following a Virgilian model - help to build the epic side of the Annales, and they contribute to the construction of a grand narrative of medieval origins for the newly founded Dutch Republic. While the phenomenon of the tournament is a good fit with Dousa's complex literary programme, it could also be used for his far less complex political purpose: resistance to the Spanish domination of the Low Countries. By representing the counts of Holland as glorious tourneyers, Dousa may be regarded as competing with the self-presentation of Habsburg rulers, such as Maximilian and Philip II, who used (real and imaginary) tournaments to legitimize their rule over the Low Countries. Moreover, Dousa presents the counts' participation in tournaments as a way to fulfil their feudal duty of faithfulness, thus contributing to the

61 For Dousa's ways of presenting the medieval counts of Holland as precursors of early modern political leaders, see also Maas C., "Was Janus Dousa a Tacitist? Rhetorical and Conceptual Approaches to the Reception of Classical Historiography and its Political Reception", in Pieper C.H. - Laureys M. - Enenkel K.A.E. (eds.), Discourses of Power: Ideology and Politics in Neo-Latin Literature, Noctes Neolatinae 17 (Hildesheim: 2012) 233248, especially $243^{-244 .}$ 
political rhetoric of the Dutch Revolt, in which the continuous loyalty of the Dutch to their legitimate rulers was frequently emphasized. In this way, the medieval phenomenon of the tournament helped Dousa to construct an appropriate past that was an excellent fit for the literary programme of his Annales as well as highly usable material for the political purposes of the Dutch Revolt.

\section{Selective Bibliography}

Dousa Janus, Annales rerum a priscis Hollandiae comitibus per CCCXLVI annos gestarum continuata serie memoriam complectentes (The Hague, Aelbrecht Hendrickszoon: 1599).

Frieder B., Chivalry and the Perfect Prince: Tournaments, Art, and Armor at the Spanish Habsburg Court, Sixteenth Century Essays and Studies 81 (Kirksville, MO: 2008).

Gelderen M. van, The Political Thought of the Dutch Revolt, 1555-1590, Ideas in Context 23 (Cambridge: 1992).

Jackson W.H., "The Tournament and Chivalry in German Tournament Books of the Sixteenth Century and in the Literary Works of Emperor Maximilian I", in Harper-Bill C. - Harvey R.E. (eds.), The Ideals and Practice of Medieval Knighthood (Woodbridge: 1986) 49-73.

Janse A., "Toernooicultuur en adelscultuur in middeleeuws Holland", Holland. Regionaal-historisch Tijdschrift 34, 3 (2002) 150-166.

Kampinga H., De opvattingen over onze oudere Vaderlandsche Geschiedenis bij de Hollandsche historici der XVIe en XVIIe eeuw (The Hague: 1917).

Maas C., 'Covered in the Thickest Darkness of Forgetfulness': Humanist Commonplaces and the Defence of Medievalism in Janus Dousa's Metrical History (1599)", in Montoya A.C. - Romburgh S. van - Anrooij W. van (eds.), Early Modern Medievalisms: The Interplay between Scholarly Reflection and Artistic Production, Intersections 15 (Leiden: 2010) 329-345.

Maas C., Medievalism and Political Rhetoric in Humanist Historiography from the Low Countries (1515-1609), Proteus 7 (Turnhout 2018).

Oudendijk J.K., "Den Coninck van Hispaengien heb ick altijt gheert", in Jappe Alberts W. (ed.), Dancwerc. Opstellen aangeboden aan Prof. Dr. D.Th. Enklaar ter gelegenheid van zijn vïfenzestigste verjaardag (Groningen: 1959) 264-278.

Peters E., "1549 Knight's Game at Binche: Constructing Philip II's Ideal Identity in a Ritual of Honour", in Falkenburg R. (ed.), Hof-, staats - en stadsceremonies, Nederlands kunsthistorisch jaarboek 49 (Zwolle: 1998) 11-35.

Rüxner Georg, Anfang, ursprung unnd herkommen des Thurniers inn teutscher nation (Siemern, Hieronymus Rodler: 1532). 
Strong R.C., Splendor at Court: Renaissance Spectacle and the Theater of Power (Boston: 1973).

Vermaseren B.A., "De werkzaamheid van Janus Dousa Sr $(\dagger 1604)$ als geschiedschrijver van Holland”, Bijdragen en mededelingen van het Historisch Genootschap 69 (1955) 49-107.

Williams G.S., "The Arthurian Model in Emperor Maximilian's Autobiographic Writings Weisskunig and Theuerdank", Sixteenth Century Journal 11, 4 (1980) 3-22. 